\title{
CAPABILITIES FOR STRATEGIC FLEXIBILITY: A COGNITIVE CONTENT FRAMEWORK
}

\author{
IAN A. COMBE \\ London Metropolitan University \\ GORDON E. GREENLEY \\ Aston Business School
}

Correspondence address:

Ian Combe

London Metropolitan University, Stapleton House,

277 - 281 Holloway Road,

London $\mathrm{N} 78 \mathrm{HN}$

Tel: 02076072789

email: 1.combe@londonmet.ac.uk 


\begin{abstract}
Different forms of strategic flexibility allow for reactively adapting to different changing environments and proactively driving change. It is therefore becoming increasingly important for decision makers to not only possess marketing capabilities, but also the capabilities for strategic flexibility in its various forms. However, our knowledge of the relationships between decision makers' different ways of thinking and their capabilities for strategic flexibility is limited. This limitation is constraining research and understanding. In this article we develop a theoretical cognitive content framework that postulates relationships between different ways of thinking about strategy and different information-processing demands. We then outline how the contrasting beliefs of decision makers may influence their capabilities to generate different hybrid forms of strategic flexibility at the cognitive level. Theoretically, the framework is embedded in resource based theory, personal construct theory and schema theory. The implications for research and theory are discussed.
\end{abstract}

Key Words:

Dynamic capabilities, Marketing capabilities, Strategy, Cognition, Competitive advantage 


\section{CAPABILITIES FOR STRATEGIC FLEXIBILITY: A COGNITIVE CONTENT FRAMEWORK \\ INTRODUCTION}

Strategic flexibility is the ability of firms to respond and successively adapt to environmental change (Chakravarthy, 1982 and 1986; Evans, 1991; Greenley and Oktemgil, 1998). The term has also been applied to strategic decision making, as it is the extent to which new and alternative options in strategic decision making are generated and considered (Aaker and Mascarenhas, 1984; Fiegenbaum and Karnani, 1991; Greenley and Oktemgil, 1998; Sharfman and Dean, 1997). Some notion of strategic flexibility is implicit in the adoption of the marketing concept, because implementing marketing suggests that firms should change to keep up with changes in present and potential customer needs. To achieve this requires options in strategic decision making to be generated by decision makers and adaptation to take place and hence some form of strategic flexibility is necessary. Grewal and Tansuhaj (2001), however, suggest that marketing capabilities are separate and different from the capabilities for strategic flexibility. They present empirical evidence to suggest that a focus on marketing capabilities in times of crisis may be less profitable than possessing the capabilities for strategic flexibility, especially as competitive intensity increases. This evidence is based on one form of strategic flexibility, a reactive form that deals with change that has already occurred, but other forms exist which are especially critical when firms operate in dynamic and changing environments (Evans, 1991). Different capabilities are probably required for other forms of strategic flexibility, such as those that deal with proactively driving change (Johnson, Lee, Saini, and Grohmann, 2003).

Strategic flexibility can offer a firm a distinctive competitive advantage, because the capabilities to generate decision making options, and hence different forms of strategic flexibility to deal with dynamic and changing environments, is probably difficult for competitors to imitate (Sanchez, 1995). Successful adaptation through strategic flexibility will likely generate superior performance, 
exacerbating the imitation problem for competitors. Consequently, it is becoming increasingly important for decision makers to possess the capabilities for strategic flexibility in its various forms. However, currently there is no adequate theoretical framework to study the capabilities for strategic flexibility.

It seems that some decision makers are more capable of generating strategic flexibility than others. Sharfman and Dean (1997) suggest an explanation for this interesting phenomenon at a cognitive level: that cognitive structures or models may influence the capabilities for strategic flexibility by limiting decision makers' thinking and blinding them from innovative decision making options. However, this notion has not been adequately developed. Therefore, there are limitations to existing knowledge, despite the potential contribution of the capabilities for strategic flexibility to effective marketing and competitive advantage.

Empirical research into the potential relationships between cognitive models and the capabilities for strategic flexibility is seemingly lacking. If these relationships could be investigated, our knowledge of these important capabilities would be considerably advanced. However, the initial major tasks in undertaking this research are defining cognitive models themselves and determining their contents, so that relationships can be postulated between cognitive models and the capabilities for strategic flexibility. In this article we develop a new cognitive content framework that addresses these initial major tasks. The contents of cognitive models are determined, a priori, based on contrasting beliefs found in the extant marketing and strategic management literatures. The framework is composed of five theoretical cognitive models: rational, developmental, deterministic, probabilistic and chaos. It illustrates that contrasting beliefs in the content of cognitive models influence decision makers' capabilities to generate different forms of strategic flexibility. By combining theoretical cognitive models with different forms of strategic flexibility (Evans, 1991), we develop and advocate new hybrid forms of strategic flexibility that take account of the capabilities of decision makers.

\section{OUTLINING THE CONSTRUCTS}


In this section we outline the key constructs that underpin the development of our cognitive content framework.

\section{Capabilities}

Capabilities are widely discussed in the 'resource based' literature and many researchers have referred to some of their constituent parts. From a resource based perspective (e.g. Collis and Montgomery, 1995; Conner, 1991; Eisenhardt and Martin, 2000; Mahoney and Pandian 1992; Penrose, 1959; Perteraf, 1993; Tallman, 1991; Teece, Pisano and Shuen, 1997; Wernerfelt, 1984) capabilities are intangible resources or assets, made up of constituents such as skills, learning and knowledge in deploying tangible or other intangible resources or assets. The capabilities for strategic flexibility can be thought of as dynamic capabilities (Eisenhardt and Martin, 2000; Teece, Pisano and Shuen, 1997), because they are associated with new resource configurations required to lead or deal with change.

\section{Strategic Flexibility}

The term strategic flexibility can be applied at two levels. First, at the level of the firm, where it is used to denote the ability of firms to respond and successively adapt to environmental change (Evans, 1991; Greenley and Oktemgil, 1998). Second, at the level of decision makers, where it is the extent to which new and alternative options in strategic decision making are generated and considered (Aaker and Mascarenhas, 1984; Fiegenbaum and Karnani, 1991; Greenley and Oktemgil, 1998; Sharfman and Dean, 1997). These two applications are not mutually exclusive, because the creation of different options by decision makers is a prerequisite for firms adapting to environment change (Sanchez, 1993; Sharfman and Dean, 1997). In other words, for strategic flexibility to exist at the level of the firm, decision makers themselves must possess capabilities for strategic flexibility. In this article we advance current theory by focusing on the capabilities of decision makers to generate different forms of strategic flexibility. 


\section{Marketing Capabilities and the Capabilities for Strategic Flexibility}

Whereas a recent study (Grewal and Tansuhaj, 2001) suggests that the capabilities for strategic flexibility and marketing capabilities are independent, the evidence for this position does not seem unequivocal. Some notion of strategic flexibility is implicit in the adoption of the marketing concept, because undertaking marketing means that firms should change to keep up with changes in present and potential market needs. To achieve this requires options in strategic decision making to be generated and adaptation to take place and hence some form of strategic flexibility is necessary (Greenley, Hooley and Saunders, 2004) and this needs to be market focused (Johnson, Lee, Saini, and Grohmann, 2003).

In some contexts such as responding to a crisis or when a firm operates in a very dynamic changing environment, however, marketing capabilities may counteract the capabilities for strategic flexibility. A main problem that seems to exist in some firms is that their marketing capabilities, including their existing knowledge base, is too focused on current customers needs and current competitors as opposed to the new. In these circumstances the marketing capabilities can act as a rigidity (Leonard-Barton, 1992; Slater and Narver, 1995) preventing strategic flexibility and adaptation to change. In this context marketing capabilities and the capabilities in strategic flexibility do seem separate and acting against each other.

Empirical evidence from the literature on innovations (e.g. Leonard-Barton, 1992; Tripsas and Gavetti, 2000) suggests that capabilities are important in explaining inertia when a new technology is knowledge destroying or competency destroying. It seems that marketing capabilities required to fulfil needs based on an old technology may act against the capabilities for strategic flexibility required to creatively fulfil new needs based on a new technology. Capabilities become more specialized through learning and through the adaptation to exploit one specific environment they become self-reinforcing and vulnerable to new capabilities offered by new organizations (Hannan and Freeman, 1984; Levinthal and March, 1993). The capabilities for strategic flexibility are 
required to help firms overcome this sort of rigidity, but further knowledge is required to understand why some decision makers seem able to overcome such rigidity whereas others cannot. As Winter (2000) points out, it is not so much a question of whether or not decision makers possess capabilities, such as the capabilities for strategic flexibility, but rather to what degree they possess them. Additionally, in this article we are concerned with the possession of the capabilities for different forms of strategic flexibility as it is unlikely that decision makers could possess capabilities for all forms.

\section{Operationalizing Strategic Flexibility in Research}

Through a review of the literature we consider that strategic flexibility has been operationalized in empirical research through three approaches: the flexible manoeuvre approach, the flexible process approach and the flexible cognitive style approach. Researchers using the manoeuvre approach take the view that strategic flexibility is an implemented form of flexibility, expressed as a particular strategic manoeuvre, at the level of the firm (e.g. Evans, 1991). For example, a pre-emptive manoeuvre is a form of strategic flexibility that can be studied at the level of the firm to see its effects on the firm and how it disrupts other firms within an industry.

In the process approach the decision-making process rather than the results of the process are studied. Here flexibility is defined as part of the strategic decision-making process, and the traits responsible for flexibility within this process are studied (e.g. Sharfman and Dean, 1997). For example, traits such as competitive aggressiveness in the strategic decision-making process may mean that some strategic decision-making processes are more flexible than other processes.

In the cognitive style approach, flexibility is regarded in terms of cognitive decision styles focused at the level of the individual decision maker (e.g. Nutt, 1993). For example, some decision makers may have a style of cognition and processing information that means they are more flexible than other decision makers. 
Whereas, proponents of the strategic manoeuvre approach do not tend to address the capabilities for strategic flexibility, because they study the results of these capabilities at the level of the firm, the proponents of the last two approaches recognise their importance. Furthermore, proponents of the cognitive style approach recognise that the capabilities for strategic flexibility exists at a cognitive level, within decision makers. What seems to be lacking from this latter cognitive stream of research, however, is an understanding of the relationships between decision makers' different cognitive models, and their capabilities for strategic flexibility. The research into individual cognitive decision styles has attempted to explore these relationships in a general way, but the results are problematic. The main problem is that the cognitive models themselves are not identified, and their contents are not specified.

Consequently, due to the inadequacy of current approaches and the need to develop a more comprehensive understanding of the relationships between decision makers' different cognitive models and their capabilities for strategic flexibility, another 'new' approach is required. In outlining this 'new' approach in this article, we clarify the content of cognitive models we consider important for strategic flexibility and postulate relationships between these cognitive models and the capabilities for strategic flexibility.

\section{TOWARDS A COGNITIVE CONTENT FRAMEWORK}

Currently, the only cognitive approach found in the literature to aid an understanding of the capabilities for strategic flexibility, is the cognitive style approach. Cognitive style is a theoretical construct used to describe an individual's manner of processing information. Some researchers suggest that cognitive style also captures aspects of an individual's belief system or cognitive content (Nutt, 1993). Others disagree, and suggest that cognitive style only describes an individual's cognitive activity, rather than the content of their cognitive models (Foxall and Bhate, 1993). In other words, how decision makers process information (their cognitive style) is not necessarily connected to what they believe (their cognitive content). 
Whereas, both cognitive style or activity and cognitive content are important for a complete understanding of the complexity of cognition, we make a start in this article by a focus on cognitive content only. In the context of this article, therefore, the nature of the cognitive style-content debate is less important, because rather than assessing cognitive style, more direct methods are available to assess the cognitive content or belief systems (what they believe) contained in the cognitive models of decision makers. One method, for example, is to explore the beliefs expressed in the content of cognitive models more directly, through psychological techniques (e.g. Markóczy and Goldberg, 1995; Walsh, 1988) based on categorization theory (Rosenberg, 1982). We suggest that research needs to focus more directly on the different beliefs, expressed in the content of cognitive models, and the potential relationships between these beliefs and different capabilities for strategic flexibility. However, these relationships remain unexplored. In this article we develop a cognitive content framework to start to address this omission.

\section{The Theoretical Bases for the Cognitive Content Framework}

From a cognitive content perspective, the capabilities for strategic flexibility are inextricably linked to information processing in decision makers. Sharfman and Dean (1997) highlight the centrality of information processing in strategic decision making, and its importance for generating decision making options to achieve strategic flexibility for the firm. The social cognition literature also highlights the centrality of information processing, when discussing the structure of cognitive models (Fiske and Taylor, 1991). This literature suggests that decision makers develop cognitive or mental models (Hodgkinson and Johnson, 1994; Porac and Thomas, 1990; Porac, Thomas and Baden-Fuller, 1989; Senge, 1990) to make sense of the environment (Daft and Weick, 1984; Day and Nedungadi, 1994; Fahey and Narayanan, 1989; Weick, 1995). Cognitive models are thought responsible for constraining the way decision makers think, and this we suggest influences their consideration of decision making options, and hence strategic flexibility. 
At a theoretical level, a cognitive content perspective is embedded in personal construct theory (Kelly, 1955) and schema theory (see Fisk and Taylor, 1991; Harris, 1996; Lord and Foti, 1986; for reviews). Personal construct theory suggests that individuals develop expectations of their environments based on theories of how the environment is structured. Schema theory suggests that individuals act on their schemas or cognitive models that represent their general knowledge about a given concept or stimulus domain (Fisk and Taylor, 1991). Both expectations and knowledge about the environment may be particularly important for the capabilities for strategic flexibility, because the learning of cause-and-effect relationships may reduce decision makers' information-processing demands (Lord and Foti, 1986), and hence their generation of decision making options.

The economy of information processing may be particularly advantageous by limiting the consideration of some decision making options and thus focusing effort on the current capabilities for some forms of strategic flexibility. For example, if decision makers can only generate a very small number of options based on their current capabilities they might speed up their choice of options considerably and therefore speed up implementation. Alternatively, there may be a heavy price to pay for this economy, because it is based on heuristics that can bias interpretations of the environment. These biased interpretations are likely to lead to a lack of recognition of change (Sparrow, 1994); the consideration of few alternative decision making options; and result in a lack of capabilities with some forms of strategic flexibility.

Through a focus on current capabilities decision makers may misinterpret the nature of change and the need to develop new capabilities in order to have a chance to exploit very profitable future opportunities. This sort of problem seems to occur when decision makers interpret change from an old technology perspective. For example, it seems that encyclopaedia book producers did not fully consider the impact of CD Rom on their book business. Firms undertaking effective marketing to current customers do not necessarily protect themselves from the need to possess the capabilities for strategic flexibility in dealing with the future based on new or alternative technologies. 
To sum up so far, we have outlined that from a resource based perspective the capabilities for strategic flexibility are dynamic capabilities important for leading or dealing with change. In changeable environments, inertia can result when too much emphasis is placed on other capabilities such as marketing capabilities if these are too focused on using current technology to fulfil current customer needs. Other such capabilities interact with and can counteract the capabilities for strategic flexibility required to lead or deal with change. The content of cognitive models may influence the capabilities for strategic flexibility, because these capabilities can be limited by biased interpretations of the environment caused by the possession of particular cognitive models. However, knowledge of the relationships between the beliefs expressed in the content of cognitive models and the capabilities for strategic flexibility is seemingly lacking. Consequently, an important first task needs to be undertaken here, that of specifying the contents of cognitive models important to the capabilities for strategic flexibility. We undertake this task next.

\section{SPECIFYING THE CONTENTS OF COGNITIVE MODELS}

Specifying the contents of cognitive models important to the capabilities for strategic flexibility is potentially a large and difficult task. The main difficulty is to determine a complete set of cognitive models that may be influential, but at this stage of theory development addressing this difficulty is beyond the scope of this article. Here, we make a start and tackle this task by focusing on one main type of cognitive model that may be most important: cognitive models of strategy. These are beliefs underpinning different ways of thinking about strategy and generating different strategic decision making options. The reason for this choice is that it is likely that different ways of thinking about strategy will influence strategic flexibility much more than other cognitive models, as they are central beliefs about adapting to the environment.

This choice does not imply that other cognitive models will have no effect on the capabilities for strategic flexibility. For example, cognitive models associated with departmental goal orientations (e.g. Dearborn and Simon, 1958; Walsh, 1988) may also have an effect. An advantage of starting 
with cognitive models of strategy is that the contents can be specified a priori, directly from the marketing and strategic management literatures. In these literatures different ways of thinking about strategy are discussed, based on different implicit beliefs. The contents of different theoretical cognitive models of strategy can be specified, therefore, by identifying the beliefs underpinning different ways of thinking about strategy.

\section{Theoretical Cognitive Models of Strategy}

Strategy theorists have conceptualized the different ways of thinking about strategy (see, for example, Combe, 1999; Hart, 1992; Minztberg, 1973; Schoemaker, 1993; Whittington, 1993). Much of the strategy theory literature is embedded in empirical research and practice, therefore it is also possible for decision makers to think about strategy in these different ways. To develop theoretical cognitive models of strategy, the extant theoretical literature on the different ways of thinking about strategy was synthesised, and tabulated around different beliefs. These models are outlined in Table 1. They are distinguished by different beliefs in relation to factors important in strategic decision making. The basis of the different theoretical cognitive models of strategy are, therefore, beliefs in relation to factors such as: the nature of the environment in which the organization operates; the predictability of change within that environment; and the possibility of change internally. We used this procedure, based on contrasting beliefs, to provide a parsimonious basis for distinguishing among different theoretical cognitive models of strategy.

\section{[Take in Table 1 about here]}

Briefly, our synthesis of the literature suggests that, rational cognitive models of strategy are based on the core belief that it is possible to predict and plan for the future by focusing on in-depth analysis and interpretation of events. Rational beliefs and ways of thinking about strategy are portrayed in much of the strategic marketing and strategic management literatures and suggest that decision makers should analyse and plan for change. 
Developmental cognitive models are based on the core belief that it is possible to develop and change for the future by focusing on exploiting current resources; building resources for the future, and the capabilities to these deploy resources. Developmental beliefs and ways of thinking about strategy are portrayed in the resource based literature and the literature on learning curve theory.

Deterministic cognitive models are based on the core belief that there are very limited possibilities to respond to external change and success is determined by external factors to the organization and decision makers. Deterministic beliefs and ways of thinking about strategy are portrayed in many forms as suggested in Table 1. In the more extreme forms one fatalistic message for management thinking is that the market largely selects firms and not the other way around.

Probabilistic cognitive models are based on the core belief that the organization exists in an interactive environment so that strategy is dependent not only on the decision maker, but competitors, other stakeholders and internal barriers to change. Probabilistic beliefs and ways of thinking about strategy are portrayed, for example, in the marketing literature dealing with the concepts of 'positioning' and 'niche', because these concepts suggest that decision makers should focus on filling gaps left by the interaction with competition.

Chaos cognitive models are based the core belief that there is a limited possibility to predict and plan for the future, because the organization exists in a complex and unpredictable environment. Chaos beliefs and ways of thinking about strategy are portrayed in different ways in the literature on Chaos theory in strategic management and the Postmodernist marketing literature.

\section{THE COGNITIVE CONTENT FRAMEWORK}

We developed this cognitive content framework from theoretical cognitive models (which were based on our interpretation of the marketing and strategic management literatures) and their main implicit beliefs presented in Table 1 in three stages. First, their different information-processing 
requirements and associated beliefs were developed from a synthesis of the literature. These are presented in Table 2.

Second, relationships were then sought, among the content of these cognitive models, and traits identified in the literature as being important to strategic decision making. A list of well-validated traits (Miles and Snow, 1978; Miller and Friesen, 1978; Lumpkin and Dess, 1996; Venkatraman, 1989) was compiled that might be important to the capabilities for strategic flexibility. An inclusive rather than exclusive approach was used to aid theory development. For example, comprehensiveness in analysis is discussed in the rational literature in strategic management, therefore there is an expectancy that the 'analysis' trait will be associated with the beliefs contained in rational cognitive models. This stage is presented in Table 3.

In stage three, relationships were also sought among the content of cognitive models and the four forms of strategic flexibility prescribed by Evans (1991). Evans (1991) has prescribed four forms of strategic flexibility: leading change through pre-emptive forms of strategic flexibility; withstanding change through protective forms; seizing the initiative for change through exploitive forms; and correcting past mistakes through corrective forms. Evans (1991) suggested that these forms of strategic flexibility are differentiated by four dimensions: two temporal dimensions with respect to change (ex ante and ex post), and two competitively intentional dimensions (offensive and defensive).

As the prescriptions were based on two temporal dimensions, and two intentional dimensions, these dimensions were analysed for links to beliefs implicit within theoretical cognitive models. Based on this analysis, the theoretical cognitive models (Table 1) are combined with the forms of strategic flexibility prescribed by Evans (1991), to develop new hybrid forms of strategic flexibility that take account of the capabilities issue at a cognitive level. A summary of the theoretical cognitive models, together with their relationships to traits within strategic decision making, and the capabilities to 
generate different forms of strategic flexibility, is presented in Table 3. The relationships among the theoretical cognitive models and the capabilities for strategic flexibility are proposed below.

[Take in Tables 2 and 3 about here]

\section{Rational Cognitive Models of Strategy}

Rational ways of thinking about strategy, that emphasise the human brain's capability to receive, organize and interpret information, are dominant in the marketing and strategic management literatures. This way of thinking is based on attempts by decision makers to reduce and rationalize complexity to try to make sense of the environment. For example, this way of thinking about strategy has been discussed in relation to information-processing models (Lord and Maher, 1990) and decision-making processes (Fredrickson and Mitchell, 1984; Hart, 1992; Hitt and Tyler, 1991; Mintzberg, 1973).

Rational cognitive models are likely to include implicit beliefs associated with rational analytical thinking. For example, that it is possible to forecast with reasonable accuracy and to deliberately plan for the future and proactively change the organization (see Table 2). The limitations of rational beliefs at a cognitive level are well documented, concerning biases in information processing and the accuracy of analysis. Some degree of stability is also required within the internal and external environments for the analytical aspects of rationalism to be effective (Ansoff, 1979; Fredrickson and Iaquinto, 1989; Fredrickson and Mitchell, 1984; Mintzberg, 1973). Therefore, incorrect interpretations of the external environment due to unpredictable change, and unforeseen internal barriers to the implementation of hierarchically imposed strategies may occur.

One idealistic purely rational view of decision making pre-supposes unlimited informationprocessing capacity by the decision maker (Lord and Maher, 1990). This view is implicit within some of the rational analytical planning literature concerned with resource allocation. A rational belief system is likely to limit and selectively direct information processing to analysis of external 
trends to reduce risk and maximize profits. There has been considerable debate on the limits of information processing, and hence the limits of rational decision making. Researchers have suggested boundedly rational (Cyert and March, 1963) and limited capacity (Lord and Maher, 1990) explanations, constrained by physiological information-processing capacity of the human brain (Miller, 1956). However, all decision makers, rational or otherwise, have to contend with physiological limitations to information processing to some degree.

Based on the above beliefs inherent in rational cognitive models of strategy, the dominant decision making traits expected to be associated with these would be analysis and proactiveness. Analysis is a trait of overall problem solving posture that encompasses the tendency to search deeper into problems and generate the best solution (Miller and Friesen, 1984; Venkatraman, 1989). Proactiveness is a trait expected in decision makers in the form of eagerness to pursue opportunities in the absence of necessity (Dutton, 1993; Mullens and Cummings, 1999; Venkatraman, 1989). This trait reflects proactive behaviour (Miles and Snow, 1978).

To develop the expected capabilities for strategic flexibility, the theoretical cognitive models are combined with the different forms of strategic flexibility (Evans, 1991) to provide new hybrid forms, focused at the capabilities of decision makers at the cognitive level. The different forms of strategic flexibility, expected to be associated with decision making based on rational cognitive models, require high degrees of analysis and varying degrees of proactiveness. The following new hybrid forms of strategic flexibility are proposed:

The Rational Corrective Form of strategic flexibility is largely focused on analysis of the external environment, because this form suggests that decision makers need to maintain an incremental fit with the external environment, by keeping up with changing customer needs and competitors' offerings. This form of flexibility requires high degrees of analysis because rational planning needs to be iterative. The marketing planning literature highlights this iterative incremental corrective approach and this has the advantage of being less risky than other forms of strategic flexibility. 
The Rational Pre-emptive Form is focused on a more balanced analysis of the internal and external environments. It is linked to an increase in proactiveness, to speedily generate new ideas and implement them to de-stabilize competitors' environments.

The Rational Exploitive Form is also focused on a more balanced analysis of the internal and external environments to proactively exploit current and new opportunities. An example of this form of strategic flexibility is the search for networks and alliances, with the objective of exploiting new markets.

The Rational Protective Form is focused on analysis of the internal environment, especially on analysis of efficiency to address risk concerns. An example of this form of strategic flexibility is the search for networks and alliances, with the objective of reducing costs and spreading risk.

Capabilities in rational decision making focusing on analysis and planning are required for the generation of strategic options utilizing these forms of strategic flexibility.

\section{Developmental Cognitive Models of Strategy}

Many researchers have highlighted the importance of resources to strategy, and the development of these resources through learning at the individual and organizational levels (Arrow, 1962; Levinthal and March, 1993; Penrose, 1959; Wernerfelt, 1984). The belief in the importance of adapting through learning from past experience (Arrow, 1962), to build difficult to imitate resources, and the capabilities to deploy these resources (Penrose, 1959, Wernerfelt, 1984), form the basis of developmental cognitive models. Writers such as Hitt, Keats and DeMarie (1998) and Sanchez (1993) have highlighted the importance of a developmental view of strategy, in particular the importance of the resource based view to strategic flexibility (Wernerfelt, 1984). A decision maker's choices are constrained by resource specificity and capabilities to use resources in a flexible manner. The contents of developmental cognitive models are likely to include implicit beliefs associated with building unique and difficult to imitate resources (see Table 2). 
Addressing developmental issues by identifying and building inimitable resources and capabilities is a difficult task, and requires decision makers to possess demanding information-processing capabilities. A developmental belief system is likely to limit and selectively direct information processing to analysis of internal resources and processes, with a view to improving them for the future. As these cognitive models are future orientated, information processing may also be influenced by a vision of the future, based on beliefs about that future.

The dominant decision-making traits expected to be associated with developmental cognitive models of strategy would be futurity and proactiveness. Futurity is a trait reflecting the temporal dimension in strategy decisions, such as an emphasis on the long or short term (Venkatraman, 1989). This trait is implicit in developmental belief systems, because of the emphasis on the longterm view in developmental strategy paradigms such as the resource based view. Proactiveness is a trait also required to engage in active learning, building resources and anticipating future problems (Lumpkin and Dess, 1996).

The different forms of strategic flexibility require high degrees of futurity and proactiveness to formulate and implement. The following new hybrid forms of strategic flexibility are proposed:

The Developmental Protective Form of strategic flexibility is based on the identification of difficult to imitate resources and capabilities. For example, companies could focus on service, research and development, or process design, as these require high degrees of co-ordination and creativity that are difficult to imitate. This form requires high degrees of futurity to focus on the longer term, and proactiveness to build difficult to imitate resources.

The Developmental Corrective Form is also based on the identification of resources and capabilities for the future. However, in this form the most appropriate resources and capabilities needed for the future are not currently present, but have to be acquired and developed over time. This form also requires high degrees of futurity and proactiveness to build resources for the future. 
The Developmental Exploitive Form is also based on the identification of unique resources and capabilities, but the focus is more on the short term rather than the long term. This form requires lower degrees of futurity, but higher degrees of proactiveness for exploiting existing resources.

Capabilities in developmental decision making focusing on identifying, exploiting and developing resources are required for the generation of strategic options utilizing these forms of strategic flexibility.

\section{Deterministic Cognitive Models of Strategy}

Deterministic cognitive models are based on the philosophy that the direction of decision making is determined by events outside management's control, and that freedom of choice is illusory (Bourgeois, 1984; Clark, Varadarajan, and Pride, 1994). Many writers have considered deterministic ways of thinking about strategy and how determinism can be implicit in strategic decision making. For example, determinism is prominent in the strategic management literature that takes an industrial organization economics perspective (Bourgeois, 1984; Grant 1996; Seth and Thomas, 1994), and is no less prominent in the marketing literature, where determinism is inherent in decision making tools based on life cycle theories such as the product life cycle (Taggart, 1995).

The population ecology literature highlights the more fundamental Darwinian deterministic view that suggests management has a passive role. From this perspective, management is largely unable to influence change and long term survival, due to structural inertia or slowness to respond to external change (Hannan and Freeman, 1984). However, a more balanced view might consider that although the external environment acts on internal company resources in a deterministic fashion, these resources have been built up through past experiences and learning (Hrebiniak and Joyce, 1985).

The contents of deterministic cognitive models are likely to include implicit beliefs associated with selection by the external environment. For example, external forces are unavoidable, and it is 
impossible to change fast enough internally to keep up with external change (see Table 2). As the success of the organization is largely determined by external forces outside the decision maker's control, it is likely that the decision maker would possess a belief system that is passive and fatalistic. Barr, Stimpert and Huff (1992) provide empirical support for this way of thinking, because in their study they found that some managers continually attributed both good and poor performance to external factors and remain passive when faced with external change.

Considerable past experience of structural inertia, may be a likely antecedent to this cognitive model. Another possible antecedent is education, in the form of acceptance of well known deterministic cyclical theories, such as the product life cycle and economic cycle theories, which suggest that performance is outside decision maker's control.

Information processing, in the context of deterministic cognitive models, may be directed to the identification of efficiency gains internally, because decision makers may consider these the only possible response to external change. Thus, a deterministic belief system may limit and selectively direct information processing to analysis of efficiency of internal processes and external cyclical trends. This way of thinking puts severe limitations on the possibility of strategic flexibility.

Based on the beliefs inherent in deterministic ways of thinking, the dominant decision-making traits expected to be associated with deterministic cognitive models of strategy would be defensiveness and proactiveness. Defensiveness is a trait that emphasises cost reduction and efficiency seeking (Venkatraman, 1989) and reflects an internally focused defensive behaviour (Miles and Snow, 1978). The proactiveness trait is expected to be associated with deterministic cognitive models in the negative form, on a continuum from proactiveness to passiveness (Lumpkin and Dess, 1996).

This different form of strategic flexibility requires high degrees of defensiveness and low degrees of proactiveness to formulate and implement. The following new hybrid form of strategic flexibility is proposed: 
The Deterministic Protective Form of strategic flexibility is based on the identification of efficient and non-efficient internal processes. The main focus may be on reducing costs as a protective measure. It requires high degrees of defensiveness to focus on efficiency gains, and high degrees of passiveness, as there is limited internal strategic response to external environmental change.

Capabilities in deterministic decision making focusing on internal efficiency are required for the generation of the strategic option utilizing these forms of strategic flexibility.

\section{Probabilistic Cognitive Models of Strategy}

Writers such as Lindblom (1959) and Mintzberg (1973) have highlighted the importance of the dynamic interactive nature of the environment, so that strategy is usually modified by probabilistic interaction with environmental factors. These interactive effects need to be addressed by decision makers, because they have to interact with internal and external limitations, which are likely to be continually changing. Internally such limitations are barriers to change, so that strategy is slowly modified and emerges incrementally from an interactive process (Lindblom, 1959, Mintzberg, 1973). Externally such limitations are the availability of market niches, so that strategy may have to be modified due to competitive exclusion.

The contents of probabilistic cognitive models are likely to include implicit beliefs associated with interactive effects. For example, that the firm is operating in a complex, dynamic, competitive environment, and is not isolated from the actions of competitors and other stakeholders. Therefore, strategy is usually modified through interaction with political barriers to change, and responses from customers and competitors (see Table 2). Decision makers with probabilistic cognitive models are likely to be very flexible, adaptive and entrepreneurial in their thinking because they continually focus on dynamic interactive effects.

Cognitive theorists have recognized these interactive effects on information processing, and suggest that some cognitive models emphasise action (Lord and Maher, 1990). For example, a 'cybernetic' 
information-processing model, where processing is dynamic and is based on feedback. A probabilistic belief system is likely to limit and selectively direct information processing to analysis of competitors, gaps in markets, and internal barriers to change.

Based on the beliefs inherent in probabilistic ways of thinking about strategy, the dominant decision-making traits expected to be associated with probabilistic cognitive models of strategy are competitive aggressiveness and recursiveness. Competitive aggressiveness is the propensity to intensively challenge competitors to achieve entry or to improve a position in markets (Lumpkin and Dess). Recursiveness is the tendency of decision makers to cycle back in their decision making processes to re-examine key assumptions (Sharfman and Dean, 1997), and this can be based on feedback and the existence of political barriers to change (Lindblom, 1959; Minztberg, 1973).

These different forms of strategic flexibility require high degrees of competitive aggressiveness and recursiveness to formulate and implement. The following new hybrid forms of strategic flexibility are proposed:

The Probabilistic Pre-emptive Form of strategic flexibility is based on the identification of niches or gaps in markets, and the notion that considerable advantage will come from filling them through first mover advantages. This form requires high degrees of competitive aggression to focus on speed of response to present opportunities.

The Probabilistic Corrective Form is based on the identification of barriers to change, such as political and cultural forces within the organization, so that strategy has to be modified incrementally by internal interaction. Strategy may also have to be incrementally modified in response to feedback from customers, though external interaction. This form requires high degrees of recursiveness to formulate and implement

The Probabilistic Protective Form is based on the identification of the interactive nature of strategy decision-making, and may be used by decision makers with considerable experience of competitive oligopolies. One of the main suggested responses to these circumstances is to build a reputation for 
retaliation against competitors, by holding grudges to ensure 'mutually assured destruction' (MAD). This form of flexibility, therefore, requires high degrees of visible competitive aggression to highlight possible retaliation.

Capabilities in probabilistic decision making focusing on dynamic interaction with other factors such as competition and barriers to change are required for the generation of the strategic options utilizing these forms of strategic flexibility.

\section{Chaos Cognitive Models of Strategy}

New ways of thinking about strategy, that stress that managers have to address complexity and unpredictability, have recently been presented. The message for decision makers from the postmodernist literature is that the consumer is very unpredictable and fickle, and therefore rational strategy is of little value (Firat, Dholakia and Venkatesh, 1995). Whereas the message from the literature addressing chaos theory suggests that decision makers need to focus on the interconnectedness of phenomena, because a small change in one part of the system can produce amplified chaos elsewhere (Senge, 1990; Stacey, 1991 and 1995).

To overcome different forms of chaos, decision makers can focus on internal responses to unpredictability, such as creative individualism or speed of reaction. Another possibility is to develop a unique organizational ideology to lead decision making. It is possible that the main advantage of possessing chaos cognitive models is that they are developed from experience and knowledge of unpredictable change. This is an advantage because unpredictable change is becoming more dominant, due to the move to global information economies (Hitt, Keats, and DeMarie, 1998; Senge 1990; Stacey, 1991; Stacey 1995). Therefore, possession of these cognitive models may be a considerable advantage to decision makers within current, dynamic business environments. Providing solutions to deal with unpredictable change, however, is more problematic. Perhaps 
Senge (1990) offers the most optimistic solution, by suggesting that decision makers should try to learn about the systemic inter-connected nature of management problems and processes.

The contents of chaos cognitive models are likely to include implicit beliefs associated with complexity and unpredictability. For example, that the external environment is unpredictable and planning is of little value, and therefore that strategy is best managed by focusing internally on creativity and speed of reaction (see Table 2). Decision makers with chaos cognitive models could be expected to be used to dealing with high levels of unpredictable change. Therefore, chaos cognitive models may encourage change and therefore generate strategic flexibility (Kiessler and Sproull, 1982).

Use of information may be limited by past experience of unpredictability or perceived unpredictability in environments, and Kiessler and Sproull (1982) suggest that these interpretations may persist in memory. The demands on information processing are the inter-connectedness of phenomena (Senge, 1990; Stacey, 1995), and non-linearity of cause-and-effect relationships over the long term.

Based on the beliefs inherent in chaos ways of thinking, the dominant decision-making traits expected to be associated with chaos cognitive models of strategy are autonomy, openness, innovativeness and riskiness. Autonomy is a trait linked to entrepreneurs, when they are said to be self-determined pioneers who act independently (Lumpkin and Dess, 1996). This trait is the tendency to act independently to bring forth a strategy idea or vision, and to carry it through to completion (Lumpkin and Dess, 1996). Innovativeness is a means for changing an organization, by generating and implementing new ideas, processes, products and services (Amabile, Conti, Coon, Lazenby and Herron , 1996; Damanpour, 1991; Stata, 1989). Openness is a trait to indicate that decision makers are receptive to new ideas and processes (Sharfman and Dean, 1997). Riskiness is the degree to which managers are willing to make speculative resource commitments in strategic decision making (Miller and Friesen, 1978). These traits are expected to be dominant in decision 
makers with experience of highly unpredictable environments, because in these circumstances decision makers are likely to develop more creative and flexible options internally, through independent innovative means. These options may be more risky for the decision makers, but they may have no option but to try to keep-up with or lead competitors in a highly changeable market.

The different forms of strategic flexibility require high degrees of autonomy, openness, innovativeness and riskiness. The following new hybrid forms of strategic flexibility are proposed:

The Chaos Exploitive Form of strategic flexibility is based on monitoring unpredictable change, such as fashion, and developing creative responses. In such situations decision makers may not attempt to predict change in advance because it is so unpredictable, but may try to exploit it when it happens. This form of flexibility, therefore, requires high degrees of autonomy, openness, innovativeness and riskiness, to focus on a speed of response to change.

The Chaos Pre-emptive Form is based on trying to anticipate and influence change, such as new technology, and developing creative responses. Decision makers can increase the unpredictable nature of the external environment for competitors, by launching innovative and creative products. This form of flexibility also requires high degrees of autonomy, openness, innovativeness and riskiness, to focus on leading change by continually developing new products.

Capabilities in chaos decision making focusing on the response to various forms of unpredictability are required for the generation of the strategic options utilizing these forms of strategic flexibility.

\section{CONCLUSION}

In this article we considered decision makers' capabilities for different forms of strategic flexibility that allow for reactively adapting to different changing environments and proactively driving change. We discussed, with reference to resource based theory, the notion that the capabilities for strategic flexibility can be thought of as dynamic capabilities associated with new resource configurations required to lead or deal with change. These capabilities, we suggested, seem to 
interact with and enhance marketing capabilities in some contexts, but these can counteract each other in other contexts, such as when marketing capabilities are too focused on current customers' needs and current competitors as opposed to the new. To aid further understanding of the capabilities for strategic flexibility we conceptually developed a 'new' cognitive content framework to postulate the relationships among the content of decision makers' cognitive models and their capabilities to generate different forms of strategic flexibility.

\section{Implications for Empirical Research}

Empirical research needs to be firstly directed to the operationalization and validation of the theoretically derived cognitive models outlined in the cognitive content framework by testing against empirical data. Following this, attention should be given to environmental effects, such as antecedent and moderating effects, and the consequences of cognitive models in terms of the capabilities to generate different forms of strategic flexibility. Additionally, research is needed to further explore the seemingly complex relationship between the capabilities for strategic flexibility and capabilities in marketing.

Exploring the Environmental Effects and Consequences. There is a substantial literature considering environmental effects on cognitive models. This literature highlights that the environment can act as an antecedent to the development of a cognitive model, and can act as a moderator between a cognitive model and its consequences. Lumpkin and Dess (1996) suggest a third possible environmental effect, as the environment can also have an independent effect on consequences. Authors suggest that cognitive models are developed due to antecedents such as culture (Hitt, Dacin, Tyler and Park, 1997; Lorsch, 1986), past experience (Brief and Downey, 1983; Ireland, Hitt, Bettis, and De Porras, 1987; Kiesler and Sproull, 1982; Prahalad and Bettis, 1986), and learning (Lord and Maher, 1990). This work should be extended to encompass the cognitive models presented in this article. 
Many contextual factors should also be studied to better understand the moderating and independent effects. Some examples studied by other researchers are: past performance (Hambrick and Snow, 1977), resources (Dutton and Duncan, 1987), slack resources (Greenley and Oktemgil, 1998; Sharfman and Dean, 1997) and the problems, opportunities and crises that strategy has to deal with (Dutton, Fahey, and Narayanan, 1983; Fredrickson, 1985; Mintzberg, Raisinghani and Théorêt, 1976; Papadakis, Lioukas and Chambers, 1998; Sharfman and Dean, 1997).

In exploring the consequences of cognitive models in terms of the capabilities to generate different forms of strategic flexibility, research needs to focus on the categorization of the consequences through finely graded forms of strategic flexibility. Some of the new hybrid forms presented in Table 3 indicate that there are various hybrid types of pre-emptive, protective, corrective and exploitive forms of strategic flexibility, and these various hybrid types need to be incorporated into research.

Exploring the Interaction of Capabilities. In highlighting the interaction between the capabilities for strategic flexibility and marketing capabilities we hope to initiate a debate and further empirical research into this interaction. Empirical evidence of this interaction is scant at present, but there is a suggestion that the capabilities for strategic flexibility can be viewed as separate and distinct from marketing capabilities. We are not so sure because both need to interact so that firms can change to meet customer needs and be effective in marketing.

Evidence also suggests that a focus on marketing capabilities in times of crisis may be less profitable than possessing the capabilities for strategic flexibility, especially as competitive intensity increases. This evidence is based on a reactive form of strategic flexibility but additional evidence needs to be collected to discover what happens in other contexts and with other forms of strategic flexibility. 


\section{Implications for Theory}

In the cognitive content framework we proposed relationships between the content of specific cognitive models and the capabilities to generate different forms of strategic flexibility, which have not been proposed to date. The relationships proposed in the framework provide a more comprehensive explanation for the different capabilities for strategic flexibility than has been presented to date. Prior to this article, the cognitive domain to help understand the capabilities for strategic flexibility implied that a single flexible decision style is responsible for generating strategic flexibility. In the framework we offer an alternative explanation, by proposing capabilities for different forms of strategic flexibility, rather than a single solution. This alternative explanation has the potential to 'open up' cognitive research into the capabilities for strategic flexibility so that it is not limited by the previous focus on cognitive style.

In the article we considered the evidence that cognitive models are developed through antecedents such as culture, past experience and learning and these are likely to be enduring and difficult for competitors to both identify and imitate. Consequently, from a resource based view the possession of a particular cognitive model by decision makers is likely to be a unique resource associated with dynamic capabilities, which has the potential to offer a firm a distinctive and sustainable competitive advantage.

Previous literature implies that all forms of strategic flexibility are open for all decision makers to use, but this seems unlikely, because it ignores the different capabilities of decision makers. In this article an alternative is presented, by linking different cognitive models to an extended range of hybrid forms of strategic flexibility we address the capabilities for strategic flexibility directly, at the level of decision makers. Furthermore, in the cognitive content framework we propose a greater number of forms of strategic flexibility than has been elucidated to date.

Previously, strategic flexibility has been presented in terms of simple alternatives expressed in a $2 \mathrm{x}$ 2 matrix, which implied that the different forms of flexibility are mutually exclusive and it is a 
matter of choice which form to use. Such a way of thinking about strategic flexibility may be constraining the development of theory, because it ignores decision makers' capabilities for generating different forms of strategic flexibility. In our cognitive content framework we address this issue. Decision makers, we contend, possess the capabilities for different forms of strategic flexibility to various degrees and the cognitive content framework presented in this article captures this type of complexity.

\section{REFERENCES}

Aaker, D.A. and Mascarenhas, B. (1984) The Need for Strategic Flexibility, Journal of Management Studies, 5, pp.74-82.

Amabile, T.M., Conti, R., Coon, H., Lazenby, J. and Herron M. (1996) Assessing the Work Environment for Creativity, Academy of Management Journal, 39, pp.1154-1184.

Ansoff, H. I. (1979) The Changing Shape of the Strategic Problem, In: Schendel, D. E. and Hofer, C. W. (eds.), Strategic Management: A New View of Business Policy and Planning Little, Brown and Co., pp. 30-44.

Arrow, K. J. (1962) The Economic Implications of Learning by Doing, Review of Economic Studies, 29, pp. 155-173.

Barr, P. S., Stimpert, J. L. and Huff, A. S. (1992) Cognitive Change, Strategic Action, and Organizational Renewal. Strategic Management Journal, 13: pp.15-36.

Bourgeois, L. J. III (1984) Strategic Management and Determinism, Academy of Management Review, 9 4, pp.586-596.

Brief, A. P. and Downey, H. K. (1983) Cognitive and Organizational Structures: A Conceptual Analysis of Implicit Organizing Theories. Human Relations, 36, 12, pp.1065-1090.

Clark, T., Varadarajan, P.R. and Pride, W.M. (1994), Environmental management: the construct and research propositions, Journal of Business Research, 29, 23-38

Collis, D.J. and Montgomery, C.A. (1995) Competing on Resources: Strategy in the 1990s, Harvard Business Review, July-Aug., pp.118-128

Combe, I. A. (1999) Multiple Strategy Paradigms: An Integrational Framework. Journal of Marketing Management, 15, pp.341-359.

Conner, K.R. (1991) A Historical Comparison of Resource-Based Theory and Five Schools of Thought Within Industrial Organization Economics: Do We Have a New Theory of the Firm?, Journal of Management, 17, 1, pp.121-154.

Cyert, R.M. and March, J.G. (1963) A Behavioral Theory of the Firm, Prentice-Hall Inc.

Daft, R. L. and Weick, K. E. (1984) Toward a Model of Organizations as Interpretation Systems, Academy of Management Review, 9, 2, pp.284-295.

Damanpour, F. (1991) Organizational Innovation: A Meta-analysis of Effects of Determinants and Moderators, Academy of Management Journal, 34, pp.555-590.

Day, G. S. and Nedungadi, P. (1994) Managerial Representations of Competitive Advantage, Journal of Marketing, 58, pp.31-44. 
Dearborn, D. C. and Simon, H. (1958) Selective Perception: A note on the Department Identifications of Executives, Sociometry, 21, pp.140-144.

Dutton, J. E. (1993) The Making of Opportunity: An Interpretative Pathway to Organizational Change. In Straw, B. M. and Cummings, L. L. (eds.) Research in OrganizationalBehavior, 15, pp.195-226.

Dutton, J. E. and Duncan, R. B. (1987) The Creation of Momentum for Change Through the Process of Strategic Issue Diagnosis. Strategic Management Journal, 8, pp279-295.

Dutton, J. E. and Jackson, S. E. (1987) Categorizing Strategic Issues: Links to Organizational Action., Academy of Management Review, 12, 1, pp.76-90.

Dutton, J. E., Fahey, L. and Narayanan, V.K. (1983) Towards Understanding Strategic Issues Diagnosis. Strategic Management Journal, 4, pp.307-323.

Eisenhardt, K.M. and Martin, J.A. (2000) Dynamic Capabilities: What are they?, Strategic Management Journal, 21, pp.1105-1121.

Evans, S. (1991) Strategic Flexibility for High Technology Manoeuvres: A Conceptual Framework. Journal of Management Studies, 28, 1, pp. 69-89.

Fahey, L. and Narayanan, V. K. (1989) Linking Changes in Revealed Causal Maps and Environmental Change: An Empirical Study, Journal of Management Studies, 26, 4, pp.361-377.

Fiegenbaum, A. and Karnani, A. (1991) Output Flexibility - A Competitive Advantage for Small Firms. Strategic Management Journal, 12, pp.101-114.

Firat, A. F., Dholakia, N. and Venkatesh, A. (1995) Marketing in a Postmodern World, European Journal of Marketing, 29, 1, pp.40-56.

Fisk, S. T. and Taylor, S. E. (1991) Social Cognition (International Edition), McGraw-Hill.

Foxall, G. R. and Bhate, S. (1993) Cognitive Style and Personal Involvement as Explicators of Innovative Purchasing of "Healthy" Food Brands, European Journal of Marketing, 27, 2, pp.5-16.

Fredrickson, J. W. (1985) Effects of Decision Motive and Organizational Performance Level on Strategic Decision Processes, Academy of Management Journal, 28, 4, pp.821-843.

Fredrickson, J. W. and Iaquinto, A. L. (1989) Inertia and Creeping Rationality in Strategic Decision Processes, Academy of Management Journal, 32, 3, pp.516-542.

Fredrickson, J. W. and Mitchell, T. R. (1984) Strategic Decision Processes: Comprehensiveness and Performance in an Industry with an Unstable Environment, Academy of Management Journal 27, pp.399-423.

Grant, R. M. (1996) Prospering in Dynamically-competitive Environments: Organizational Capability as Knowledge Integration, Organizational Science, 7, pp.375-387.

Greenley, G. E. and Oktemgil, M. A. (1998) Comparison of Slack Resources in High and Low Performing British Companies, Journal of Management Studies, 35, 3, pp.377-398.

Greenley, G., Hooley, G. and Saunders, J. (2004) Management Processes in Marketing Planning, European Journal of Marketing, forthcoming.

Grewal, R. and Tansuhaj, P. (2001) Building Organizational Capabilities for Managing Economic Crisis: The Role of Market Orientation and Strategic Flexibility, Journal of Marketing, 65, April, pp.67-80.

Hambrick, D. C. and Snow, C. C. (1977) A Contextual Model of Strategic Decision-making in Organizations. In Taylor, R. L., O Connell, M. J., Zawacki, R. A. and Warrick, D. D. (eds.) Academy of Management Proceedings, pp.109-112. 
Hannan, M. T. and Freeman, J. (1984) Structural Inertia and Organizational Change, American Sociological Review, 49, pp.149-164.

Harris, S. G. (1996) Organizational Culture and Individual Sensemaking: A Schema-Based Perspective. In Meindl, J. R., Stubbart, C. and Porac, J. F. (eds.) Cognition Within and Between Organizations, Sage, pp.283-306.

Hart, S. L. (1992) An Integrative Framework for Strategy-Making Processes, Academy of Management Review, 17, 2, pp.327-351.

Hitt, M. A. and Tyler, B. B. (1991) Strategic Decision Models: Integrating Different Perspectives, Strategic Management Journal, 12, pp.327-351.

Hitt, M. A., Dacin, M. T., Tyler, B. B. and Park, B. (1997) Understanding the Differences in Korean and U.S. Executives Strategic Orientations, Strategic Management Journal, 18, 2, pp.159-167.

Hitt, M. A., Keats, B. W. and DeMarie, S. M. (1998) Navigating in the New Competitive Landscape: Building Strategic Flexibility and Competitive Advantage in the $21^{\text {st }}$ Century, Academy of Management Executive, 12, 4, pp.22-42.

Hodgkinson, G. P. (1997) The Cognitive Analysis of Competitive Structures: A Review and Critique. Human Relations, 50, 6, pp.625-654.

Hodgkinson, G. P. and Johnson, G. (1994) Exploring the Mental Models of Competitive Strategists: The Case for a Processual Approach, Journal of Management Studies, 31, 4, pp.525-551.

Hrebiniak, L. G. and Joyce, W. F. (1985) Organizational Adaptation: Strategic Choice and Environmental Determinism, Administrative Science Quarterly, 30, pp.336-349.

Ireland, R. D., Hitt, M. A., Bettis, R. A. and De Porras, D. A. (1987) Strategy Formulation Processes: Differences in Perceptions of Strength and Weaknesses Indicators and Environmental Uncertainty by Managerial Level, Strategic Management Journal, 8, pp.469-485.

Johnson, J.L., Lee, R.P., Saini, A. and Grohmann, B. (2003) Market-Focused Strategic Flexibility:

Conceptual Advances and an Integrative Model, Journal of the Academy of Marketing Science,

Vol.31,No.1, pp. 74-89.

Kelly, G. A. (1955) The Psychology of Personal Constructs, Norton.

Kiesler, S. and Sproull, L. (1982) Managerial Response to Changing Environments, Perspectives on Problem Sensing from Social Cognition, Administrative Science Quarterly, 27, pp.548-570.

Leonard-Barton, D. (1992) Core Capabilities and Core Rigidities: A Paradox in Managing New Product Development, Strategic Management Journal, Vol.13,pp.111-125.

Levinthal, D. A. and March, J. G. (1993) The Myopia of Learning, Strategic Management Journal, 14, pp.95-112.

Lindblom, C. E. (1959) The Science of Muddling Through, Public Administration Review, 19, pp.79-88.

Lord, R. G. and Foti, R. J. (1986) Schema Theories, Information Processing, and Organizational Behaviour, In: Sims, H. P. Gioia, D. A. and Ass. (eds.), The Thinking Organization, Jossey- Bass, pp.20-48.

Lord, R. G. and Maher, K. J. (1990) Alternative Information Processing Models and Their Implications for Theory, Research, and Practice, Academy of Management Review, 15, 1, pp.9-28.

Lorsch, J. W. (1986) Managing Culture: The Invisible Barrier to Strategic Change, California Management Review, 28, 2, pp.95-109.

Lumpkin, G. T. and Dess, G. G. (1996) Clarifying the Entrepreneurial Orientation Construct and Linking it to Performance, Academy of Management Review, 21, 1, pp.135-172. 
Mahoney, J.T. and Pandian, J.R. (1992) The Resource-Based View within the Conversation of Strategic Management, Strategic Management Journal, Vol.13,pp.363-380.

Markóczy, L. and Goldberg, J. (1995) A Method for Eliciting and Comparing Causal Maps, Journal of Management, 21, 2, pp.305-333.

Markus, H. (1977) Self-Schemata and Processing Information about the Self, Journal of Personality and Social Psychology, 35, 2, pp.63-78.

Miles, R. E. and Snow, C. C. (1978) Organizational Strategy, Structure and Process, McGraw-Hill.

Miller, D. and Friesen, P. H. (1978) Archetypes of Strategy Formulation, Management Science, 24, 9, pp.921-933.

Miller, D. and Friesen, P. H. (1984) Organizations: A Quantum View, Prentice-Hall Inc.

Miller, G. A. (1956) The Magic Number Seven Plus or Minus Two: Some Limits to our Capacity for Processing Information, Psychology Review, 50, pp.81-97.

Mintzberg, H. (1973) Strategy-Making in Three Modes, Californian Management Review, XV1, 2, pp.49-53.

Mintzberg, H., Raisinghani, D. and Théorêt, A. (1976) The Structure of "Unstructured" Decision Processes, Administrative Science Quarterly, 21, pp.246-275.

Mullens, J. W. and Cummings, L. L. (1999) Situational Strength: .A Framework for Understanding the Role of Individuals in Initiating Strategic Change, Journal of Organizational Change, 12, pp.462-479.

Nutt, P. C. (1993) Flexible Decision Styles and the Choice of Top Executives, Journal of Management Studies, 30, 5, pp.695-721.

Papadakis, V. M., Lioukas, S. and Chambers, D. (1998) Strategic Decision-Making Processes: The Role of Management and Context, Strategic Management Journal, 19, pp.115-147.

Penrose, E. T. (1959) The Theory of the Growth of the Firm, Basil Blackwell.

Perteraf, M.A. (1993) The Cornerstones of Competitive Advantage: A Resource-Based View, Strategic Management Journal, 14, pp.179-191.

Porac, J. F. and Thomas, H. (1990) Taxonomic Mental Models in Competitor Definition, Academy of Management Review, 15, pp.224-240.

Porac, J. F., Thomas, H. and Baden-Fuller, C. (1989) Competitive Groups as Cognitive Communities: The Case of the Scottish Knitwear Manufacturers, Journal of Management Studies, 26, 4, pp.397-416.

Prahalad, C. K. and Bettis, R. A. (1986) The Dominant Logic: A New Linkage between Diversity and Performance, Strategic Management Journal, 7, pp.485-501.

Rosenberg, S. (1982) The Method of Sorting in Multivariate Research with Application Selected from Cognitive Psychology and Personal Perception. In: Hirschberg, N. and Humphreys, L. G. (eds.), Multivariate Applications in the Social Sciences, Erlbaum, pp. 117-142.

Sanchez, R. (1993) Strategic Flexibility, Firm Organization, and Managerial Work in Dynamic Markets: Strategic Options Perspective. In: Shrivastava, P., Huff, A. and Dutton, J. (Eds), Advances in Strategic Management, JAI Press, 9, pp.251-291.

Sanchez, R. (1995) Strategic Flexibility in Product Competition, Strategic Management Journal, 16, pp.135-159.

Schoemaker, P. J. H. (1993) Strategic Decisions in Organizations: Rational and Behavioural Views. Journal of Management Studies, 30, 1, pp.107-129. 
Senge, P. M. (1990) The Fifth Discipline: The Art and Practice of the Learning Organization. Century Business.

Seth, A. and Thomas, H. (1994) Theories of the Firm: Implications for Strategy Research, Journal of Management Studies, 31, 2, pp.165-191.

Sharfman, M. P. and Dean, J. W. Jr. (1997) Flexibility in Strategic Decision-making: Informational and Ideological Perspectives, Journal of Management Studies, 34, 2, pp.191-217.

Slater, S. F. and Narver, J. C. (1995) Market Orientation and the Learning Organization, Journal of Marketing, Vol.59,July,pp.63-74.

Sparrow, P. R. (1994) The Psychology of Strategic Management: Emerging Themes of Diversity and Cognition. In: Cooper, C. L. and Robertson, I. T. (eds.), International Review of Industrial and Organizational Psychology, John Wiley \& Sons Ltd.

Sproull, L. S. (1981) Beliefs in Organizations, In Nystrom, P. C. and Starbuck, W. H. (eds.), Handbook of Organizational Design, Oxford University Press, pp.166-202.

Stacey, R. D. (1991) The Chaos Frontier, Butterworth-Heinemann.

Stacey, R. D. (1995) The Science of Complexity: An Alternative Perspective for Strategic Change Processes, Strategic Management Journal, 6, pp.477-495.

Stata, R. (1989) Organizational Learning - The Key to Management Innovation, Sloan Management Review, 30, pp.63-74.

Taggart, J. H. (1995) Strategy Formulation in Declining Industries: A Biology Paradigm, Journal of Marketing Management, 11, pp.295-314.

Tallman, S.B. (1991) Strategic Management Models and Resource-Based Strategies among MNEs in a Host Market, Strategic Management Journal, 12, pp.69-82.

Teece, D.J., Pisano, G, and Shuen, A. (1997) Dynamic Capabilities and Strategic Management, Strategic Management Journal, Vol.18, pp.509-531.

Tripsas, M. and Gavetti, G. (2000) Capabilities, Cognition and Inertia: Evidence from Digital Imaging, Strategic Management Journal, 21, pp.1147-1161.

Venkatraman, N. (1989) Strategic Orientation of Business Enterprises: The Construct, Dimensionality, and Measurement. Management Science, 35, 8, pp.942-962.

Walsh, J. P. (1988) Selectivity and Selective Perception: An Investigation of Managers Belief Structures and Information Processing, Academy of Management Journal, 31, 4, pp.873-896.

Weick, K. E. (1995) Sensemaking in Organizations, Sage Publications.

Wernerfelt, B. (1984) A Resource-based View of the Firm, Strategic Management Journal, 5, pp.171-180.

Whittington, R. (1993) What is Strategy and does it matter? Routledge.

Winter, S. (2000) The Satisficing Principle in Capability Learning, Strategic Management Journal, 21, pp.981-996. 
Table 1. Theoretical Cognitive Models of Strategy

\begin{tabular}{|c|c|c|c|c|c|}
\hline $\begin{array}{l}\text { Theoretical } \\
\text { Cognitive Models }\end{array}$ & Rational & Developmental & Deterministic & Probabilistic & Chaos \\
\hline $\begin{array}{l}\text { Main Implicit } \\
\text { Beliefs }\end{array}$ & $\begin{array}{l}\text { Possible to predict and } \\
\text { plan for the future }\end{array}$ & $\begin{array}{l}\text { Possible to develop } \\
\text { and change }\end{array}$ & $\begin{array}{l}\text { Impossible (or very } \\
\text { limited possibility) } \\
\text { to develop and } \\
\text { change at } \\
\text { organizational level. } \\
\text { Passive and } \\
\text { fatalistic }\end{array}$ & $\begin{array}{l}\text { Strategy contingent } \\
\text { on internal and } \\
\text { external factors }\end{array}$ & $\begin{array}{l}\text { Impossible or } \\
\text { limited possibilities } \\
\text { to predict and plan }\end{array}$ \\
\hline $\begin{array}{l}\text { Basis of Belief } \\
\text { System }\end{array}$ & $\begin{array}{l}\text { Based on cognitive } \\
\text { capacity, analysis and } \\
\text { interpretation }\end{array}$ & $\begin{array}{l}\text { Based on resources } \\
\text { and capabilities }\end{array}$ & $\begin{array}{l}\text { Based on selection. } \\
\text { Strategy determined } \\
\text { by outside events }\end{array}$ & Based on interaction & $\begin{array}{l}\text { Based on complexity } \\
\text { and unpredictability }\end{array}$ \\
\hline $\begin{array}{l}\text { The Associated } \\
\text { Literatures }\end{array}$ & $\begin{array}{l}\text { Rational Planning } \\
\text { Modernist - Scientific } \\
\text { management } \\
\text { Functionalist - } \\
\text { Bureaucracy and } \\
\text { T.Q.M. } \\
\text { Holistic - Network, } \\
\text { Stakeholder }\end{array}$ & $\begin{array}{l}\text { Evolutionary } \\
\text { (Larmarkian) } \\
\text { Process } \\
\text { (Developmental) - } \\
\text { learning by doing } \\
\text { Resource based } \\
\text { view }\end{array}$ & $\begin{array}{l}\begin{array}{l}\text { Evolutionary } \\
\text { (Darwinian) }\end{array} \\
\text { Population ecology } \\
\text { literature } \\
\text { addressing } \\
\text { structural inertia, } \\
\text { Life cycles, } \\
\text { Structural } \\
\text { Contingency theory, } \\
\text { Industrial } \\
\text { organization } \\
\text { economics }\end{array}$ & $\begin{array}{l}\text { Ecological } \\
\text { Process (Emergent) } \\
\text { - adaptive, } \\
\text { incremental) } \\
\text { Game Theory } \\
\text { Behavioural } \\
\text { Social Contextual } \\
\text { Contingency } \\
\text { Theory }\end{array}$ & $\begin{array}{l}\text { Postmodernist } \\
\text { Postmodernist } \\
\text { Marketing } \\
\text { Chaos Theory }\end{array}$ \\
\hline
\end{tabular}


Table 2. Content of Theoretical Cognitive Models of Strategy and the Expected Influence on Information Processing

\begin{tabular}{|c|c|c|c|c|c|}
\hline $\begin{array}{l}\text { Theoretical } \\
\text { Coonitive Models }\end{array}$ & Rational & Developmental & Deterministic & Probabilistic & Chaos \\
\hline Expected Beliefs & $\begin{array}{l}\text { It is possible to } \\
\text { undertake analysis and } \\
\text { provide internal } \\
\text { explanations of } \\
\text { phenomena present in } \\
\text { both the internal and } \\
\text { external environment } \\
\text { It is possible to forecast } \\
\text { with reasonable } \\
\text { accuracy and } \\
\text { deliberately plan for } \\
\text { the future and } \\
\text { proactively change the } \\
\text { organization } \\
\text { Analysis, forecasting } \\
\text { and formulation of } \\
\text { strategies can be best } \\
\text { conducted through a } \\
\text { hierarchical } \\
\text { management system } \\
\text { based on planning } \\
\text { procedures } \\
\text { Subsequent } \\
\text { implementation is also } \\
\text { best achieved through } \\
\text { this command and } \\
\text { control system }\end{array}$ & $\begin{array}{l}\text { It is possible to } \\
\text { develop and } \\
\text { change by learning } \\
\text { Firms need to build } \\
\text { resources and } \\
\text { capabilities for the } \\
\text { future } \\
\text { Firms need to build } \\
\text { unique difficult to } \\
\text { imitate resources }\end{array}$ & $\begin{array}{l}\text { External forces are } \\
\text { unavoidable } \\
\text { It is impossible to } \\
\text { change fast enough } \\
\text { internally to keep up } \\
\text { with external change } \\
\text { Strategy is best } \\
\text { focused on internal } \\
\text { issues such as cost } \\
\text { efficiencies, because } \\
\text { differentiation and } \\
\text { change is impossible } \\
\text { (probably usually } \\
\text { due to lack of } \\
\text { resources) }\end{array}$ & $\begin{array}{l}\text { The firm is operating } \\
\text { in a complex, } \\
\text { dynamic competitive } \\
\text { environment and is } \\
\text { not isolated from the } \\
\text { moves of others } \\
\text { Strategy is usually } \\
\text { modified by } \\
\text { interaction with } \\
\text { others } \\
\text { Decision makers } \\
\text { have to craft strategy } \\
\text { to take account of } \\
\text { political barriers to } \\
\text { implementation and } \\
\text { responses from } \\
\text { customers and } \\
\text { competitors } \\
\text { Strategy needs to } \\
\text { incorporate speed of } \\
\text { reaction to changing } \\
\text { customer needs and } \\
\text { competitive moves }\end{array}$ & $\begin{array}{l}\text { The external } \\
\text { environment is } \\
\text { unpredictable and } \\
\text { planning is of little } \\
\text { value } \\
\text { There is a need to } \\
\text { analyse fashion } \\
\text { and/or technology } \\
\text { trends but these are } \\
\text { relatively } \\
\text { unpredictable } \\
\text { Strategy is best } \\
\text { managed by } \\
\text { focusing internally } \\
\text { on creativity and } \\
\text { reactive speed }\end{array}$ \\
\hline $\begin{array}{l}\text { Expected } \\
\text { Influence on } \\
\text { Information } \\
\text { processing }\end{array}$ & $\begin{array}{l}\text { Focused on analysis, } \\
\text { predicting and } \\
\text { planning to reduce risk } \\
\text { and maximize profits }\end{array}$ & $\begin{array}{l}\text { Focused on } \\
\text { identifying key } \\
\text { resources and } \\
\text { capabilities for the } \\
\text { future and the lack } \\
\text { of these }\end{array}$ & $\begin{array}{l}\text { Focused on internal } \\
\text { processes for } \\
\text { efficiency gains }\end{array}$ & $\begin{array}{l}\text { Focused on } \\
\text { identifying gaps } \\
\text { externally and } \\
\text { barriers to change } \\
\text { internally }\end{array}$ & $\begin{array}{l}\text { Focused on internal } \\
\text { creativity and new } \\
\text { product } \\
\text { development }\end{array}$ \\
\hline
\end{tabular}


Table 3. Theoretical Cognitive Models of Strategy and the Expected Relationships to the Capabilities to Generate Different Forms of Strategic Flexibility

\begin{tabular}{|c|c|c|c|c|c|}
\hline $\begin{array}{l}\text { Theoretical } \\
\text { Cognitive Models }\end{array}$ & Rational & Developmental & Deterministic & Probabilistic & Chaos \\
\hline $\begin{array}{l}\text { Expected } \\
\text { Dominant } \\
\text { Decision making } \\
\text { Traits }\end{array}$ & $\begin{array}{l}\text { Analysis } \\
\text { Proactiveness } \\
\text { (for monitoring and } \\
\text { seeking) }\end{array}$ & $\begin{array}{l}\text { Futurity } \\
\text { Proactiveness } \\
\text { (for building) }\end{array}$ & $\begin{array}{l}\text { Defensiveness } \\
\text { Proactiveness } \\
\text { (negative -i.e. } \\
\text { passiveness) }\end{array}$ & $\begin{array}{l}\text { Competitive } \\
\text { aggressiveness }\end{array}$ & $\begin{array}{l}\text { Autonomy } \\
\text { Innovativeness } \\
\text { Openness } \\
\text { Riskiness }\end{array}$ \\
\hline $\begin{array}{l}\text { The Expected } \\
\text { Capabilities for } \\
\text { Strategic } \\
\text { Flexibility }\end{array}$ & $\begin{array}{l}\text { Pre-emptive } \\
\text { (Proactive strategy } \\
\text { based on analysis of } \\
\text { trends and planning) } \\
\text { Exploitive (Form } \\
\text { networks to exploit } \\
\text { new markets) } \\
\text { Corrective (Iterative } \\
\text { planning to provide } \\
\text { continual fit with } \\
\text { changing external } \\
\text { environment) } \\
\text { Protective (Reduce } \\
\text { risks and cut costs by } \\
\text { forming networks) }\end{array}$ & $\begin{array}{l}\text { Corrective (Build } \\
\text { resources and } \\
\text { capabilities for the } \\
\text { future) } \\
\text { Exploitive } \\
\text { (Exploit existing } \\
\text { resources) } \\
\text { Protective (Build } \\
\text { difficult to imitate } \\
\text { resources) }\end{array}$ & $\begin{array}{l}\text { Protective (Focus } \\
\text { on internal processes } \\
\text { - e.g. reduce costs as } \\
\text { a protective } \\
\text { measure) }\end{array}$ & $\begin{array}{l}\text { Pre-emptive (Fill } \\
\text { niche before } \\
\text { someone else and } \\
\text { exclude others) } \\
\text { Corrective } \\
\text { (Incremental } \\
\text { emergent changes; } \\
\text { corrective measures } \\
\text { based on positive/ } \\
\text { negative feedback) } \\
\text { Protective (MAD - } \\
\text { Counter aggression } \\
\text { with aggression - } \\
\text { game theory) }\end{array}$ & $\begin{array}{l}\text { Pre-emptive } \\
\text { (Develop new } \\
\text { products - based on } \\
\text { innovation and } \\
\text { creativity; lead } \\
\text { change by } \\
\text { continually changing } \\
\text { products) } \\
\text { Exploitive (Exploit } \\
\text { current fashion) }\end{array}$ \\
\hline
\end{tabular}




\section{Acknowledgements}

The authors would like to thank Andrea Baller, and the Editors and anonymous reviewers of the European Journal of Marketing, all of whom provided constructive comments on early drafts of this article. Addressing these comments has considerably improved the article.

\section{Biographical Details}

Ian Combe is a Senior Lecturer in Strategic Marketing at London Metropolitan University. Previously, he held a position at Aston University, Birmingham, UK. His research interests lay in multi-paradigm views of strategy, strategic orientation and strategic flexibility.

Gordon Greenley is Professor of Marketing and Head of Faculty at Aston Business School, Aston University, and Head of the Marketing Group. He is a Fellow of the British Academy of Management. His research interests are centred around competitive advantage, stakeholder orientation and marketing planning. His work has been widely published, including the Journal of Business Research, European Journal of Operational Research, International Journal of Research in Marketing, Journal of Management Studies, Journal of Market Focused Management, Omega: the International Journal of Management Science, and Strategic Management Journal. 